\title{
Human development and knowledge management: A fresh look
}

\author{
Maria Sarabia $^{1 *}$, Maria Obeso ${ }^{1}$, Marta Guijarro ${ }^{1}$ and Carmen Trueba ${ }^{2}$ \\ ${ }^{1}$ Department of Business Administration, University of Cantabria, Avda. de los Castros, s/n, 39005 Santander, \\ Cantabria, Spain. \\ ${ }^{2}$ Department of Economics, University of Cantabria, Avda. de los Castros, s/n, 39005 Santander, Cantabria, Spain.
}

Accepted 13 January, 2012

\begin{abstract}
This paper presents a new approach to knowledge management and shows a relationship between human development and knowledge management in different countries. This study demonstrates the idea that the growth of countries depends on how each one manages their knowledge; investing in research and development, improving their production function and obtaining a welfare state which allows people to develop better their human capabilities. Our study includes an analysis of different organizations of countries: European Union, Organization for Economic Co-operation and Development (OECD), G-20, Cairns, Asian-Pacific Economic Cooperation (APEC), Mercosur, BRIC and Next-11 (N-11). We identified five factors in the study using a rotated component matrix, which explained more than the $69.85 \%$ of the data: (1) knowledge creation potential; (2) ICT productivity; (3) knowledge internationalization; (4) research results and (5) education motorway. This paper provides an interesting focus on knowledge management and human development and our results show important links between countries which manage their knowledge correctly and efficiently and their level of human development. In consequence, countries that correctly manage their knowledge present a high human development level.
\end{abstract}

Key words: Knowledge management, human development index, countries results.

\section{INTRODUCTION}

For many years enterprises have valued knowledge and its importance in creating value (Villela and Muniz, 2010). However, in the case of countries themselves, knowledge management is not recognized yet as a key strategy for international competitiveness. In the last decade, some research has suggested that knowledge management could improve administrative efficiency and provide more accurate information (Misra and Hariharan, 2003; Prokopiadou et al., 2004; Saussois, 2003). In this way, this paper provides an exploratory study of countries in which governmental strategies based on expenditures on research and development lead to human development.

Knowledge management has been identified as a

${ }^{\star}$ Corresponding author. E-mail: sarabiam@unican.es. Tel: +34942-201-636. Fax: +34-942-201-890. crucial factor for competitive success in organizations (Shin et al., 2001; Bhatti et al., 2011). Different economic theories have studied knowledge as a fascinating and powerful factor. According to Penrose (1959), economists have always recognized the dominant role that increasing knowledge plays in economic process. But knowledge is treated from different perspectives concerning the ways to acquire and utilize it. For example, Marshall (1965), a classical economist, held that capital is formed by organization and, to a great extent, knowledge: "knowledge is our most powerful engine of production".

Globalization, technological advances and competitive advantages are the main elements associated with the new knowledge economy and they contribute to national productivity, competitive advantages and industrial performance (Orlando and Verba, 2005; Goldberg, 2006; Martinus, 2010). This approach has brought out the knowledge component of labor productivity which also 
contributes to national productivity. In this sense, several scholars hold that innovation, or the generation of technical knowledge which has positive effects on economic and productivity growth. Lederman and Maloney (2003), used regressions with data panels of five-year averages between 1975 and 2000 with over 53 countries in order to find that a one-percentage point increase in the ratio of total research expenditure to GDP increases the growth rate of GDP by $0.78 \%$ points. Another interesting study by Guellec and Van Pottelsberghe (2001) holds that public and foreign $R$ and $D$ all have statistically significant positive effects on productivity growth.

Technical knowledge contributed significantly to the total factor productivity growth of U.S. manufacturing industries during the period of 1953 to 1980 according to Adams (1990), who used a great collection of academic and scientific papers from various scientific fields to proxy for the stock of knowledge. In this way, Poole and Bernard (1992) provide evidence for military innovations in Canada showing that the defense-related stock of innovation had a significant negative effect on the total factor productivity growth of four industries over the period of 1961 to 1985 (Chen and Dahlman, 2004).

Following Jones (2002), growth in any particular country is driven by the implementation of ideas discovered throughout the world. This stock of ideas is proportional to worldwide research effort, which in turn is proportional to the total population of innovation countries. Using human capital as an input and ideas and innovation as outputs defines the new knowledge production function.

In this new scenario, the aim of this paper is focused on the idea that the growth of countries depends on how each one manages their knowledge, investing in research and development, improving their production function and obtaining a welfare state which allows people to improve the development of their human capabilities. In this sense, we have outlined the idea of how countries manage their knowledge. That is to say, we proposed a cross country study which attempts to measure the investment variables and resulting variables related to the knowledge component. In this sense, we identified five organizational success parameters in a country's knowledge management. After that, these results are compared to the Human Development Index (HDI) of the countries trying to explain the relationship between this human development and their knowledge management.

\section{LITERATURE REVIEW}

Different economic theories have studied knowledge as an interesting power factor. The Austrian school of economics by Hayek and Schumpeter showed knowledge in economic affairs. Meanwhile, Hayek (1945) classified knowledge into scientific knowledge and context-specific, Schumpeter (1951) emphasized the importance of combining explicit knowledge. In fact, he pointed out combinations of knowledge from new products, production methods and organizations.

Penrose (1959) was who focused on the growth of the individual firms using its mental models by appraising its strengths and weaknesses. In this way, the firm could find these images in its experience and knowledge. At this moment, knowledge is related with the growth of the firm but it is not included in the organizational mechanism through which firm's members can process knowledge. Nelson and Winter $(1977,1982)$ defined the concept of knowledge repository. Such knowledge was also recognized as the essence of innovation but not was linked at that moment to the creation of technological knowledge in organizational processes. The evolution of knowledge concept has tried to find a scientific line (Taylor, 1911) reducing the knowledge into rules for applying them to daily work and a humanistic line (Mayo, 1933) developing social human skills to facilitate organizational relationships.

The scientific and humanistic management views were synthesize by Barnard (1938) who emphasized the importance of behavioral knowledge in the management processes. Polanyi (1966) overemphasized this behavioral knowledge or non-linguistic mental process defining a tacit viewpoint of knowledge. In this sense and inspired by Barnard et al. (1958) built a scientific theory of problem solving and decision making based on the concept of bounded rationality which was included in his computer model of the human thought. Thus, Simon (1973) further argued that knowledge is used in deciding course of action and in consequence, in each formulated strategy by executive managers in the organization. Human potential for creating knowledge was neglected for the moment.

Following the evolution to the present knowledge concept, Porter $(1980,1985)$ developed a framework for analyzing competitive advantages in the firms thanks to his famous five-force model and his value chain model. Both models assumed the relevance of knowledge into organizational strategy. But Drucker (1993) was the visionary who suggested the term of knowledge society and the role of knowledge worker. In this sense, Quinn (1992) established the key points for the configuration of intangible values (technological know-how).

In the way of the fittest survival in turbulent economy, knowledge and the firm's capacity for learning represent the cure of many organizations which suffer the accelerated technological change. This organizations' need to adapt themselves to change as defined by Argyris and Schön (1978) with two kinds of learning: single-loop and double loop. Senge (1990) also proposed the learning organization as a new paradigm. At the same moment, Prahalad and Hamel (1990) offered a new approach based on resources as competencies, capabilities, skills and strategic assets. They defined sustainable competitive advantage on core competences of the firm. 
Building knowledge framework and linking it with learning is another interesting concept that is observed as culture. Schein (1985) argued that culture is a learned product of group experience. Thus, Pfeffer (1981) defined organizations as systems of shared meanings and beliefs. Following Nonanka and Takeuchi (1995), organizational culture is observed in beliefs and knowledge shared by members of the firm. Looking for how organizations create new products and new internal processes, a new concept (Knowledge) is defined as very important. Knowledge is how organizations create new knowledge that makes such creations possible, presents a fundamental need for the firm (Nonaka and Takeuchi, 1995). Knowledge management is fundamental in order to obtain competitive advantages in organizations. The knowledge management concept is ambiguous because it includes some activities like data extraction, analysis, storage, dissemination and use (Lancioni and Chandran, 2009), thus, its definition is not of a singular nature nor is commonly accepted (Hlupic et al., 2002). In this sense, there are numerous definitions that have been proposed by some scholars across time. For example, Petrash (1996) defined the knowledge management concept as a process where organizations obtain adequate knowledge with appropriate people in the correct time and place. Another example was proposed by Huang et al. (1999), who defined knowledge management as an organizational and structural process in which instruments and infrastructure create, store and reuse knowledge in organizations. Recently, Kebede (2010) defined the concept as being systematic and characterized knowledge management, and also the management of all the processes and instruments associated with this asset, as having a specific goal: to exploit its potential serving as a support for decision making, facilitating innovation and creating a competitive advantage on all levels within the organization. In some definitions, we can become familiarized with the principal activities related to knowledge management:

1. Knowledge creation (De Jarnet, 1996; Swann et al., 1999; Bhatt, 2001; Holm, 2001; Canals, 2003; Chawla and Joshi, 2010; Dow and Pallaschke, 2010).

2. Knowledge identification (Bassi, 1997; Hibbard, 1997; Quintas et al., 1997; Snowden, 1998; Heisig, 2009; Dow and Pallaschke, 2010).

3. Knowledge acquisition (Bassi, 1997; Swan et al., 1999; Alavi and Leidner, 2001; Magnier-Watanabe and Senoo, 2008; Dow and Pallaschke, 2010).

4. Knowledge development (Dow and Pallaschke, 2010). 5. Knowledge distribution (De Jarnet, 1996; Hibbard, 1997; Alavi and Leidner, 2001; Bhatt, 2001; Holm, 2001; Magnier-Watanabe and Senoo, 2008; Dow and Pallaschke, 2010).

6. Knowledge use (De Jarnet, 1996; Quintas et al., 1997; Bhatt, 2001; Holm, 2001; Heisig, 2009; Dow and Pallaschke, 2010).

7. Knowledge share (Swann et al., 1999; Bhatt, 2001;
Holm, 2001; Canals, 2003; Magnier-Watanabe and Senoo, 2008; Heisig, 2009; Chawla and Joshi, 2010). 8. Knowledge store (De Jarnet, 1996; Heisig, 2009; Dow and Pallaschke, 2010).

In this sense, knowledge management is not only collected as stored data and information: knowledge management is an organizational level process and all related people must share their knowledge and therefore, the organization will exploit its competitive advantages in order to achieve success.

\section{METHODOLOGY}

\section{Data source}

Data for this study were drawn from the Bank World Database. So our paper includes several different organizations of countries: European Union, Organization for Economic Co-operation and Development (OECD), G-20, Cairns, Asian-Pacific Economic Cooperation (APEC), Mercosur, BRIC and Next-11 (N-11). 2005 is the year in which there is the least amount of missing data and as such, we have selected it for our study in order to obtain more conclusions about the other countries.

\section{Description of variables}

The variables have been classified into the following categories: (1) country description, (2) investment and (3) performance (Table 1). All of them are related directly or indirectly with knowledge within these countries. These variables have been selected according to past contributions about knowledge management where authors highlight some factors in this area (Table 2).

\section{Research method}

In this study, we applied the factor analysis technique described by Kim and Mueller (1994) as a "variety of statistical techniques whose objective is to represent a set of variables in terms of a smaller number of underlying variables or factors". In this sense, common factor analysis is used to "identify underlying factors or dimensions reflecting what the variables share in common" (Hair et al., 1995: 375). This technique helps researchers "make sense of large bodies of interrelated data" (Hair et al., 1995: 404). Thus, factor analysis was used in this study to identify the critical factors in the countries for managing knowledge. Principal component analysis (PCA) with Varimax rotation is also used in the study. Hair et al. (1995: 380) recommend rotation because it "simplifies the factor structure and usually results in more meaningful factors".

\section{RESULTS}

\section{Construct validity}

In our study, the KMO (Kaiser Meyer Olkin Coefficient) measure of sampling adequacy reveals that the $\mathrm{KMO}$ is 0.715 . Also, the $p$ value of Bartlett's test is 0 (less than the explicit level of 0.05) (Cronbach, 1970). These tests explain that factor analysis is appropriate for these data (Table 3). 
Table 1. Description of variables analyzed for the different organizations of countries.

\begin{tabular}{lll}
\hline Descriptive variables & Investment variables & Performance variables \\
\hline Population density & ITC expenditure & GDP growth \\
Number of researchers & R+D expenditure & GDP per capita \\
Number of technicians & Education expenditure & Patents \\
Internet users & & Scientific articles \\
Royalties and license fees & & New enterprises rate \\
High-tech exports & & Unemployed rate \\
Collection of royalties and license fees & & \\
ITC exports & & \\
ITC imports & & \\
ITC services exports & & \\
\hline
\end{tabular}

Source: Own work from World Bank

\section{Exploratory factor analysis}

Using a rotated component matrix (Table 4), we defined five factors in the study, which explained more than the $69.85 \%$ of the data (Table 5). Hair et al. (1995: 378) argued that "it is not uncommon to consider a solution that accounts for $60 \%$ as satisfactory". Consequently, we can consider our study to be satisfactory. The five critical factors that have been identified for managing knowledge in countries are: (1) knowledge creation potential; (2) ICT productivity; (3) knowledge internationalization; (4) research results and (5) education motorway.

Factor 1: Knowledge creation potential: This first factor represents $28.94 \%$ of variability and includes the following variables: GPD per capita, number of technicians, collection of royalties, number of researchers, internet users, $R+D$ expenditure, number of scientific articles and GPD growth. In this way, these variables could be linked to the concepts of knowledge workers and knowledge creation. $R+D$ investment is directly linked to knowledge management because the process of knowledge creation depends on how each country invests in resources to obtain new ideas (Nussbaum, 2000). This investment in research is one of the most important elements for the country's growth due to the fact that it represents the essence of the scientific knowledge (Romer, 1990). For example, the scientific papers published allowed us to account for the new knowledge which is transformed into patents (Gans et al., 2005).

Factor 2: ICT productivity: The second factor represents around $18 \%$ of data variability and includes variables linked to information and communication technology. ICT investment promotes activities based on exports and imports which provide a platform for sharing knowledge between countries (Greenan et al., 2001). Intensive use of ICT reduces the effort in R and $D$ which creates scale economies for the enterprises which operate in these countries (Cerquera and Klein, 2008; Polder et al., 2009). The relationship between ICT and enterprises productivity is, in general, positive (Bresnahan, 2002; Castiglione, 2009).

Factor 3: Knowledge internationalization: The third factor explains more than 8 per cent of data variability and includes the following variables: ICT services exports and royalties. In this fashion, the capacity for internationalization of a company depends on the management of its developed know-how between its business units around the world. So, ICT services are key issues for obtaining more royalties from the international business units within a multinational company. The franchising process is an example of how knowledge that can be exported to other countries through licensing agreements (know-how).

Factor 4: Research results: The fourth factor represents more than $7 \%$ of the variability and includes variables linked to research results: the ratio of new enterprises and the ratio of number of new patents. In this sense, Romer (1990) specified that the production of scientific knowledge plays a key role in economic growth.

Factor 5: Education motorway: The last factor represents more than $7 \%$ of data variability and exposes the relevance of the education expenditure on unemployment. The education process is therefore vital for the growth of countries. In this sense, basic education is necessary in order to increase learning ability and the use of information while higher education is related to the improvements on knowledge creation (Chen and Dahlman, 2004).

\section{DISCUSSION}

This paper identifies five crucial factors for countries interested in managing their knowledge efficiently: 
Table 2. Variables and authors who emphasize their importance.

\begin{tabular}{|c|c|}
\hline Variables & Authors who highlight the importance of these variables \\
\hline Population density & $\begin{array}{l}\text { Acs, Anselin and Vorga, 2002; Jones, 2002; Li, 2002; Varga and Schalk, 2004; Arnold, 2006; Berliant, Reed y Wang, } \\
\text { 2006; Tsé, 2008; Martinus, 2010. }\end{array}$ \\
\hline Internet users & Chen and Dahlman, 2004. \\
\hline Number of researchers & $\begin{array}{l}\text { OECD, 2001; Florida, 2002; Jones, 2002; Glaeser and Saiz, 2003; Chen and Dahlman, 2004; Florida and Tinagli, } \\
\text { 2004; Raspe and Van Oort, 2006; Lee and Choi, 2008; Martinus, } 2010 .\end{array}$ \\
\hline Number of technicians & $\begin{array}{l}\text { OECD, 2001; Florida, 2002; Jones, 2002; Glaeser and Saiz, 2003; Chen and Dahlman, 2004; Florida and Tinagli, } \\
\text { 2004; Raspe and Van Oort, 2006; Lee and Choi, 2008; Martinus, } 2010 .\end{array}$ \\
\hline High-tech exports & Cerquera and Klein, 2008; Polder, Leeuwen, Mohnen and Raymond, 2009. \\
\hline ICT imports and exports & Cerquera and Klein, 2008; Polder, Leeuwen, Mohnen and Raymond, 2009. \\
\hline Royalties and license fees & Lee and Choi, 2008. \\
\hline Education expenditure & Chen and Dahlman, 2004; Goddard, 2007; Martínez-Fernández, Rerceretnam and Sharpe, 2007. \\
\hline ITC expenditure & $\begin{array}{l}\text { Greenan, Topiol-Bensaid and Mairesse, 2001; Bresnahan, 2002; Cerquera and Klein, 2008; Castiglione, 2009; Polder, } \\
\text { Leeuwen, Mohnen and Raymond, 2009. }\end{array}$ \\
\hline $\mathrm{R}+\mathrm{D}$ expenditure & $\begin{array}{l}\text { Kogut and Zander, 1992; Henderson and Cockburn, 1994; Davidsson and Segerstrom, 1998; Fleming, 2001; } \\
\text { Lederman and Maloney, 2003; Chen and Dahlman, 2004; Lindström and Heshmati, 2005; Comisión Europea, } 2007 .\end{array}$ \\
\hline GDP growth & $\begin{array}{l}\text { Acs, Anselin and Varga, 2002; Jones, 2002; Li, 2002; Lederman and Maloney, 2003; Chen and Dahlman, 2004; Varga } \\
\text { and Schalk, 2004; Arnold, 2006; Berliant, Reed and Wang, } 2006 .\end{array}$ \\
\hline GDP per capita & $\begin{array}{l}\text { Acs, Anselin and Varga, 2002; Jones, 2002; Li, 2002; Lederman and Maloney, 2003; Chen and Dahlman, 2004; Varga } \\
\text { and Schalk, 2004; Arnold, 2006; Berliant, Reed and Wang, 2006. }\end{array}$ \\
\hline Unemployed rate & $\begin{array}{l}\text { Acs, Anselin and Varga, 2002; Jones, 2002; Li, 2002; Lederman and Maloney, 2003; Chen and Dahlman, 2004; Varga } \\
\text { and Schalk, 2004; Arnold, 2006; Berliant, Reed and Wang, } 2006 .\end{array}$ \\
\hline Patents & $\begin{array}{l}\text { Romer, 1990; North, 1991; Jones, 2002; Gans, Murray and Stern, 2005; Raspe and Van Oort, 2006; Murray and } \\
\text { O'Mahony, 2007; Furman and Stern, 2008; Lee and Choi, } 2008 .\end{array}$ \\
\hline Scientific articles & $\begin{array}{l}\text { Romer, 1990; North, 1991; Jones, 2002; Gans, Murray and Stern, 2005; Raspe and Van Oort, 2006; Murray and } \\
\text { O'Mahony, 2007; Furman and Stern, 2008; Lee and Choi, } 2008 .\end{array}$ \\
\hline New enterprises rate & Hansen, Nohra and Tierney, 1999; Fletcher and Polychronakis, 2007; King, Kruger and Pretorius, 2007. \\
\hline
\end{tabular}

Own work from World Bank source.

"Knowledge creation potential", "ICT Productivity", "Knowledge internationalization", "Research results" and "Education motorway". These results provide evidence that a countries' growth depends on how it manages its knowledge, investing in research and development, improving its production function and obtaining a welfare state which allows people to further develop their human capabilities.

At this point, we consider it appealing to identify similar behaviours concerning knowledge management between the countries studied. Firstly, a cross-factor analysis is proposed in order to obtain factors which summarize the knowledge variables: "Knowledge creation potential" and "ICT productivity". Factors 1 and 2 explain the $50.72 \%$ of the data which allows us to study a representative sample of countries. But the knowledge variables obtained from the World Bank source are not enough to explain the relationship between good practices and knowledge (which means proper investment in knowledge and good results on GDP). In this sense, we tried to explain that knowledge management could allow the 
Table 3. KMO and Bartlett's test.

\begin{tabular}{cccc}
\hline \multirow{2}{*}{ Kaiser-Meyer-Olkin measure of Sampling adequacy } & \multicolumn{3}{c}{ Bartlett's test of sphericity } \\
\cline { 2 - 4 } & Approx. Chi-Square & Df & Significance \\
\hline 0.715 & 821.094 & 171 & 0 \\
\hline
\end{tabular}

Source: Own work from World Bank.

Table 4. Rotated component matrix.

\begin{tabular}{lccccc}
\hline \multirow{2}{*}{ Variable } & \multicolumn{5}{c}{ Component } \\
\cline { 2 - 6 } & $\mathbf{1}$ & $\mathbf{2}$ & $\mathbf{3}$ & $\mathbf{4}$ & $\mathbf{5}$ \\
\hline GPD per capita & 0.915 & - & 0.107 & - & - \\
Researchers & 0.870 & 0.113 & - & 0.201 & 0.120 \\
Technicians & 0.864 & - & - & -0.101 & - \\
Internet users & 0.851 & 0.227 & -0.145 & 0.108 & - \\
Scientific articles & 0.806 & - & - & 0.203 & 0.113 \\
Royalties collection & 0.746 & 0.119 & 0.258 & - & -0.123 \\
R+D expenditure & 0.688 & - & 0.108 & 0.470 & - \\
GDP growth & -0.457 & - & 0.275 & -0.277 & - \\
ITC exports & - & 0.931 & - & - & - \\
ITC imports & -0.109 & 0.924 & 0.120 & - & - \\
High technology exports & 0.176 & 0.774 & 0.104 & 0.153 & 0.190 \\
ITC expenditure & 0.173 & 0.683 & -0.206 & 0.184 & - \\
No population density & - & 0.621 & - & -0.296 & 0.126 \\
ITC services exports & - & -0.144 & 0.867 & - & - \\
Royalties & 0.215 & 0.305 & 0.690 & -0.116 & - \\
Patents & 0.277 & 0.138 & -0.147 & 0.751 & - \\
New enterprises & 0.438 & 0.168 & -0.201 & -0.468 & 0.368 \\
Unemployment & -0.222 & -0.102 & -0.129 & -0.136 & -0.804 \\
Education expenditure & -0.321 & 0.134 & - & -0.135 & 0.664 \\
\hline
\end{tabular}

Extraction method: Principal component analysis. Own work from World Bank source.

Table 5. Total variance explained.

\begin{tabular}{ccccc}
\hline \multirow{2}{*}{ Component } & \multicolumn{3}{c}{ Rotation sums of squared loadings } \\
\cline { 2 - 5 } & 1 & Total & \% of Variance & Cumulative (\%) \\
\hline \multirow{4}{*}{ Factor } & 5.499 & 28.941 & 28.941 \\
& 2 & 3.448 & 18.150 & 47.091 \\
& 3 & 1.572 & 8.275 & 55.366 \\
& 4 & 1.394 & 7.339 & 62.705 \\
& 5 & 1.358 & 7.145 & 69.850 \\
\hline
\end{tabular}

Extraction method: Principal component analysis. Source: Own work from World Bank

country to improve its human development.

Following the human development report issued by the United Nations Development Programme (UNDP, 1990), human development is a process of enlarging the opportunities of human beings, taking into account the three most important: a long and healthy life, access to education and a decent standard of living. According to this definition, health, education and per capita income are the three dimensions that contribute to the enhancement human beings' capabilities. The HDI is a compound index that measures average achievement of a region's population by means of these dimensions (Appendix 1).

An exploratory analysis of data through the k-means cluster analysis, makes classifying the selected countries 
Table 6. Analysis cluster results.

\begin{tabular}{|c|c|c|c|c|c|}
\hline & & \multicolumn{4}{|c|}{ Classification according to knowledge management } \\
\hline & & 1 & 2 & 3 & 4 \\
\hline \multirow{3}{*}{ 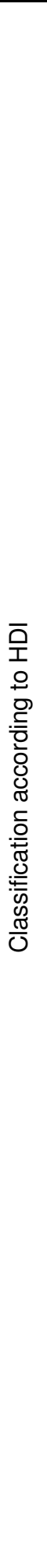 } & 1 & $\begin{array}{l}\text { Norway } \\
\text { Australia } \\
\text { New Zealand } \\
\text { United States } \\
\text { Ireland } \\
\text { Netherlands } \\
\text { Canada } \\
\text { Sweden } \\
\text { Germany } \\
\text { Japan } \\
\text { France } \\
\text { Finland } \\
\text { Iceland } \\
\text { Belgium } \\
\text { Denmark } \\
\text { Luxembourg } \\
\text { Austria } \\
\text { United Kingdom }\end{array}$ & $\begin{array}{l}\text { Switzerland } \\
\text { Israel } \\
\text { Spain } \\
\text { Greece } \\
\text { Italy } \\
\text { Czech Republic } \\
\text { Slovenia } \\
\text { Slovakia } \\
\text { Estonia } \\
\text { Cyprus }\end{array}$ & $\begin{array}{l}\text { Korea (Republic of) } \\
\text { Malta } \\
\text { Hungary } \\
\text { Brunei Darussalam }\end{array}$ & $\begin{array}{l}\text { Hong Kong, China (SAR) } \\
\text { Singapore }\end{array}$ \\
\hline & 2 & & $\begin{array}{l}\text { Portugal } \\
\text { Poland } \\
\text { Lithuania } \\
\text { Chile } \\
\text { Argentina } \\
\text { Latvia } \\
\text { Romania } \\
\text { Uruguay } \\
\text { Saudi Arabia } \\
\text { Bulgaria } \\
\text { Peru } \\
\text { Russian Federation }\end{array}$ & $\begin{array}{l}\text { Mexico } \\
\text { Costa Rica }\end{array}$ & Malaysia \\
\hline & 4 & & $\begin{array}{l}\text { Iran (Islamic Republic of) } \\
\text { Brazil } \\
\text { Colombia } \\
\text { Turkey } \\
\text { Bolivia } \\
\text { Paraguay } \\
\text { Egypt } \\
\text { Indonesia } \\
\text { Viet Nam } \\
\text { Guatemala } \\
\text { India } \\
\text { Pakistan } \\
\text { Bangladesh } \\
\text { Papua New Guinea } \\
\text { Nigeria }\end{array}$ & $\begin{array}{l}\text { China } \\
\text { Thailand } \\
\text { South Africa }\end{array}$ & Philippines \\
\hline
\end{tabular}

The countries within each cluster are order following their HDI for the 2010. Source: Own work from UNDP (2010) and World Bank (2005). 
Table 7. Estimations of the Spearman's rank coefficient $(2007,2008,2009$ 2010).

\begin{tabular}{ll}
\hline Year & $\mathbf{2 0 1 0}$ \\
\hline 2007 & 0.999 \\
2008 & 1.000 \\
2009 & 1.000 \\
\hline
\end{tabular}

Statistically significant results $(p<0.0001)$. Own work from UNDP (2010).

possible according to the human development level and knowledge variables. The knowledge variables are extracted from the year 2005 and the HDI variables are from the period of 2007 to 2010 (Appendix 2). They show that human development is explained by correct and efficient knowledge management taking into account that positive knowledge results are obtained along the way. This multivariate technique provides groups of countries which present similarities in their behaviour. Table 6 explained the obtained classifications comparing the knowledge management study of the two factors selected ("Knowledge creation potential" and "ICT productivity") and the values of the HDI from the considered period.

The cluster analysis resulting from HDI provides a classification which matches the knowledge management cluster analysis in $56 \%$ of the countries. This fact could be observed in the principal diagonal shown in Table 6. It is quite interesting that this high concordance is particularly important for the countries which present the best knowledge management (Norway, Australia, New Zealand, United States, Ireland, Netherlands, Canada, Sweden, Germany, Japan, France, Finland, Iceland, Belgium, Denmark, Luxembourg, Austria and United Kingdom). All these countries are classified in the first cluster of HDI, corresponding to the countries which present high human development. In addition, there is a $59 \%$ concordance between the countries which belong to the clusters 1 and 2 in both classifications. This means that the countries which present a high human development are those which previously have also adequately managed their knowledge.

We are able to conclude that the countries in the clusters 1 and 2 present higher human development level during the period due to the fact that there is an important concordance between the classifications of the countries according to their HDI during that period. Using a hypothesis test based on the Spearman's rank coefficient, the null hypothesis of non relationship between the HDl's classifications of the countries each year $(2007,2008$ and 2009) and 2010 is contrasted. Table 7 shows that there is a high level of concordance between the classifications presenting values close to 1 and the significance of the results.

\section{Conclusions}

This paper provides a new focus on how the growth of countries is related to their knowledge management in terms of investing in research and development, improving their production function and, in consequence, how their welfare state is able to develop higher human capabilities.

Our study includes different organizations of countries for analysis: European Union, Organization for Economic Co-operation and Development (OECD), G-20, Cairns, Asian-Pacific Economic Cooperation (APEC), Mercosur, BRIC and Next-11 (N-11).

Using a rotated component matrix we defined five factors in the study, which explained more than the $69.85 \%$ of the data. Consequently, our study is considered satisfactory. There are five critical factors for managing knowledge efficiently: (1) knowledge creation potential; (2) ICT productivity; (3) knowledge internationalization; (4) research results and (5) education motorway. Trying to link the knowledge management and country human development, we used the Human Development Index (HDI) from United Nations Development Programme (UNDP, 1990). In this sense, Factors 1 and 2 explained the $50.72 \%$ of the data variability. The cluster analysis allows the selected countries to be classified according to the human development level and the knowledge variables. This analysis resulting from HDI provides a classification which matches the knowledge management cluster analysis in $56 \%$ of the countries. All these countries are classified in the first cluster of HDI, corresponding to the countries which present a high human development. As we commented previously in the discussion, there is a $59 \%$ of concordance between the countries which belong to the clusters 1 and 2 in both classifications.

This paper provides an interesting look at knowledge management and human development and our results show important links between countries which properly and efficiently manage their knowledge and their level of development. And as such, countries who manage their knowledge correctly present a high level of human development. Regarding future projects, we proceed to apply the same technique for analyzing knowledge management to other interesting groups of countries such as NATO.

\section{ACKNOWLEDGMENTS}

The authors would like to thank the Ministerio de Ciencia e Innovación (project ECO2010-15455) for their support.

\section{REFERENCES}

Acs Z, Anselin L, Varga A (2002). Patents and innovation counts as measures of regional production of new knowledge. Res. Policy, 31(7): 1069-1085.

Adams JD (1990). Fundamental stocks of knowledge and productivity growth. J. Polit. Econ., 98(4): 673-702.

Alavi M, Leidner DE (2001). Knowledge management and knowledge management systems: conceptual foundations and research issues. 
MIS Q., 25(1):107-136.

Argyris C, Schön DA (1978). Theory in practice: A theory of action perspective. Addison-Wesley, Reading.

Arnold $L$ (2006). The dynamics of the Jones $R \& D$ growth model. Rev. Econ. Dynam., 9: 143-52.

Barnard Cl (1938). The functions of the executive. Harvard University Press, Cambridge, MA.

Bassi LJ (1997). Harnessing the power of intellectual capital, In The knowledge management yearbook (1999-2000). Cortada JW, Woods JA (eds.), Butterworth-Heinemann, Boston.

Berliant M, Reed R, Wang P (2006). Knowledge exchange, matching, and agglomeration. J. Urban. Econ., 60: 69-95.

Bhatt $G$ (2001). Knowledge management in organization: Examining the interaction between technologies, techniques and people. J. Know. Manage., 5(1): 68-75.

Bhatti WA, Zaheer A, Rehman KU (2011). The effect of knowledge management practices on organizational performance: A conceptual study. Afr. J. Bus. Manage., 5(7): 2847-2853.

Bresnahan TF (2002). Information technology, workplace organization and the demand for skilled labor: Firm-level evidence. Q. J. Econ., 117(1): 339-376.

Canals A (2003). La gestión del conocimiento. In: Acto de presentación del libro Gestión del Conocimiento, Barcelona.

Castiglione C (2009). ICT investment and firm technical efficiency. XI European Workshop on Efficiency and Productivity Analysis (EWEPA), Pisa, Italia.

Cerquera D, Klein GJ (2008). Endogenous firm heterogeneity, ICT and RyD incentives. ZEW Discussion Paper No. 08-126.

Chawla D, Joshi H (2010). Knowledge management initiatives in Indian public and private sector organizations. J. Know. Manage., 14(6): 811-827.

Chen DHC, Dahlman CJ (2004). Knowledge and development: A crosssection approach. World Bank Policy Research. Working paper \#3366.

Comisión Europea (2007). Hechos y cifras clave sobre Europa y los europeos. Working paper.

Cronbach LJ (1970). Essentials of psychological testing. Harper \& Row.

Davidson C, Segerstrom P (1998). R\&D subsidies and economic growth. J. Econ., 29(3): 558-577.

De Jarnet L (1996). Knowledge, the latest thing. Inf. Strat. Exec. J., 12(2): 3-5.

Dow RM, Pallaschke S (2010). Managing knowledge for spacecraft operations at ESOC. J. Know. Manage., 14(5): 659-677.

Drucker PF (1993). The new productivity challenge. Harv. Bus.s Rev. Nov.-Dec.: 69-79.

Fleming $L$ (2001). Recombinant uncertainty in technological search. Manage. Sci., 47(1): 117-132.

Fletcher L, Polychronakis YE (2007). Capturing knowledge management in the supply chain. EuroMed J. Bus., 2(2): 191-2007.

Florida R (2002). The rise of the creative class. Basic Books, New York, NY.

Florida R, Tinagli I (2004). Europe in the creative age. Carnegie Mellon Software Industry Center, Pittsburgh, PA.

Furman J, Stern S (2008). Climbing atop the shoulders of giants: The impact of institutions on cumulative research. Working paper, National Bureau of Economic Research, Cambridge, MA.

Gans JS, Murray FE, Stern S (2005). Patents, papers, pairs y secrets: Contracting over the disclosure of scientific knowledge. Working paper.

Glaeser E, Saiz A (2003). The rise of the skilled city. Discussion Paper 2025, Harvard Institute of Economic Research, Cambridge, MA.

Goddard J (2007). The engagement of higher educational institutions in regional development: an overview of the opportunities and challenges. Globally Competitive, Locally Engaged Higher Education and Regions, OECD/IMHE International Conference Proceedings, Valencia, Spain.

Goldberg M (2006). Knowledge creation, use and innovation: the role of urban and regional innovation strategies and policies. Eur. Plan. Stud., 14(5): 641-64.

Greenan N, Topiol-Bensaid A, Mairesse J (2001). Information technology and research and development impacts on productivity and skills: Looking for correlations on French firm level data, In
Information Technology, Productivity and Economic Growth. Pohjola, M. (ed.), Oxford University Press.

Greenan N, Topiol-Bensaid A, Mairesse J (2001). Information technology and research and development impacts on productivity and skills: Looking for correlations on French firm level data. In Information Technology, Productivity and Economic Growth, Pohjola, M. (ed.), Oxford University Press.

Guellec D, van Pottelsberghe de la Potterie B (2001). R\&D and productivity growth: Panel data analysis of 16 OECD Countries. STI Working Papers. Organization for Economic Co-operation and Development.

Hair JF, Anderson RE, Tatham R, Black W (1995). Multivariate data analysis. Englewood Cliffs, NJ: Prentice Hall.

Hansen MT, Nohria N, Tierney T (1999). What's your strategy for managing knowledge?. Harvard Bus. Rev., 77(2): 106-16.

Hayek F (1945). The use of knowledge in society. Am. Econ. Rev., XXXV (4): 519-530.

Heisig P (2009). Harmonisation of knowledge management-comparing $160 \mathrm{KM}$ frameworks around the globe. J. Know. Manage., 13: 4-31.

Henderson RM, Cockburn I (1994). Measure competence: Exploring firm effects in pharmaceutical research. Strateg. Manage., 15: 63-84.

Hibbard J (1997). Knowing what we know. Inf. Week. 20 October.

Hlupic V, Pouloudi A, Rzevski G (2002). Towards an integrated approach to knowledge management: 'Hard', 'soft' and 'abstract' issues. Know. Proc. Manage., 9(2): 90-102.

Holm J (2001). Capturing the spirit of knowledge management. 37th American Conference on Information Systems, Boston, MA.

Huang K, Lee, YW, Wang RY (1999) Calidad de la información y gestión del conocimiento, AENOR, Madrid.

Jones C (2002). Sources of US economic growth in a world of ideas. Am. Econ. Rev., 92(1): 220-39.

Kebede G (2010). Knowledge management: An information management perspective. Inter. J. Inform. Sci., 30: 416-424.

Kim J-O, Mueller CW (1994). Factor analysis: statistical methods and practical issues. Part II. In M.S. Lewis-Beck (ed.), Factor analysis and related techniques. London: Sage.

King N, Kruger CJ, Pretorius J (2007). Knowledge management in a multicultural environment: a South African perspective. Aslib Proc. 59(3): 285-299.

Kogut B, Zander U (1992). Knowledge of the firm, combinative capabilities and the replication of technology. Organ. Sci., 3(3): 383397.

Lancioni RA, Chandran R (2009). Managing knowledge in industrial markets: new dimensions and challenges. Ind. Mark. Manage., 38(2): 148-151.

Lederman D, Maloney WF (2003). R\&D and development. Policy Research Working Paper, 3024, The World Bank.

Lee M, Choi H (2008). Dynamic changes in creative manpower and RyD technology level in the culture industry. 26th International Conference of the System Dynamics Society, Atenas, Greece.

Li C (2002). Growth and scale effects: the role of knowledge spillovers. Econ. Lett., 74(2): 177-185.

Lindström O, Heshmati A (2005). The impact of public funds on private R\&D investment: New evidence from a firm level innovation study. MTT Discussion Papers 3, Agrifood Research Finland, Finland.

Magnier-Watanabe R, Senoo D (2008). Organizational characteristics as prescriptive factors of knowledge management initiatives. J. Know. Manage., 12(1): 21-36.

Martínez-Fernández C, Rerceretnam M, Sharpe S (2006). Intellectual assets in urban regions: UWS in western Sydney. UWS Urban Research Centre, Penrith.

Martinus K (2010). Planning for production efficiency in knowledgebased development. J. Know. Manage., 14(5): 726-743.

Mayo E (1933). The human problems of an industrial civilization. Macmillan, New York.

Misra DC, Hariharan R (2003). E- knowledge management framework for government organizations. Inf. Syst. Manage., Spring: 38-48.

Murray F, O'Mahony S (2007). Re-conceptualizing the institutional foundations of cumulative innovation. Organ. Sci.

Nelson RR, Winter SG (1977). In search of a useful theory of innovation. Res. Pol., 6(1): 36-77.

Nonaka I, Takeuchi H (1995). The knowledge-creation company: How 
Japanese companies create the dynamics of innovation. Oxford University Press, Nueva York.

North DC (1991). Institutions. J. Econ. Persp., 5(1): 97-112.

Nussbaum M (2000). Women and human development: The capabilities approach, Cambridge University Press, Cambridge, RU.

OECD (2001). Knowledge, work organisation and economic growth. Labour Market and Social Policy-Occasional Papers, 50, DEELSA/ELSA/WD3, Paris.

Orlando M, Verba M (2005). Do only big cities innovate? Technological maturity and the location of innovation. Econ. Rev, Federal Reserve Bank Kansas City. Q (2): 31-57.

Penrose ET (1959). The theory of the growth of the firm. Oxford: Basil Blackwell

Petrash G (1996). Managing knowledge assets for value. KnowledgeBased Leadership Conference, Linkage Inc., Boston, October.

Pfeffer J (1981). Power in organizations. Pitman Pub., Marshfield.

Polanyi M (1966). The tacit dimension. Routledge and Kegan Paul, London.

Polder M, Van Leeuwen G, Mohnen P, Raymond W (2009). Productivity effects of innovation modes. Statistics Netherlands Discussion. Paper \#09033.

Poole E, Bernard JT (1992). Defence Innovation Stock and Total Factor Productivity Growth. Can. J. Econ., 25(2): 438-52.

Porter ME (1985). Competitive advantage. The Free Press, New York.

Porter ME (1980). Competitive strategy. The Free Press, New York.

Prahalad CK, Hamel G (1990). The core competence of the corporation. Har. Bus. Rev., 68(1): 79-91.

Prokopiadou G, Papatheodorou C, Moschopoulos D (2004). Integrating knowledge management tools for government information. Gov. Inform. Q., 21: 170-198.

Quinn JB (1992). Intelligent enterprise: A knowledge and service based paradigm for industry. The Free Press, New York.

Quintas P, Lefrere P, Jones G (1997). Knowledge management: A strategic agenda. Long Range Plann., 30(3): 385-391.

Raspe O, Van Oort F (2006). The knowledge economy and urban economic growth. Eur. Plann. Stud., 14(9): 1209-1234.

Romer PM (1990). Human capital and growth: Theory and evidence. Carnegie-Rochester Conference Series on Public Policy. 32(0): 251286.
Saussois JM (2003). Knowledge management in government: An idea whose time has come. OECD J. Budget., 3(3): 105-120.

Schein EH (1985). Organizational culture and leadership. Jossey-Bass, San Francisco, CA.

Schumpeter JA (1951). The theory of economic development. Harvard University Press, Cambridge, MA.

Senge EH (1990). The fifth discipline: The art and practice of the learning organization. Doubleday, New York.

Shin M, Holden T, Schmidt RA (2001). From knowledge theory to management practice: towards an integrated approach. Inform. Process. Manag., 37: 335-355.

Simon HA (1973). Applying information technology to organization design. Pub. Adm. Rev., 33: 268-278.

Snowden D (1998). A framework for creating a sustainable knowledge management program. In The knowledge management yearbook 1999-2000, Cortada JW, Woods JA. Butterworth-Heinemann, Boston.

Taylor FW (1911). The principles of scientific management. Harper and Brothers, New York.

Tse $C$ (2008) Learning investment and industrial diversity in urban growth. Rev. Econ. Dyn., 11(2): 413-433.

UNDP (1990). Human Development Report 1990. Oxford University Press, New York.

UNDP (2010). Human Development Report 2010. The real wealth of nations pathways of human development, Palgrove McMillan, New York.

Varga A, Schalk H (2004). Knowledge spillovers, agglomeration and macroeconomic growth: an empirical approach. Reg. Stud., 38(8): 977-989.

Villela-Dantas JR, Muniz-Farias PP (2010). Conceptual navigation in knowledge management environments using NavCon. Inform. Process. Manag., 46: 413-425. 


\section{APPENDIX}

\section{Appendix 1. Calculating the HDI}

The HDI is a summary measure of three dimensions of the human development: health (measured by life expectancy at birth), education (mean years of schooling, expected years of schooling) and per capita income (gross national income per capita in PPP US\$). Each variable is transformed into an intermediate index by the general formula:

intermediae index $=\frac{\text { actualvalue- } \text { minimun vhe }}{\text { maximun vkue- } \text { minimun vkue }}$

The maximum and minimum values (goalposts) are 83.2 and 20 years for life expectancy at birth, 13.2 and 0 for average years of schooling, 20.6 and 0 for expected years of schooling and \$108,211.00 and 163.00 PPP US \$ for GNP per capita.

The previous formula, together with the aforementioned goalposts, leads to $I_{H}, I_{K}$ and $I_{I}$, intermediate indices of health, education and per capita income, respectively. Then, the HDI is the simple geometric average of the three intermediate indices:

$$
\mathrm{HDI}=\left(I_{H} \cdot I_{K} \cdot I_{I}\right)^{1 / 3}
$$

Appendix 2. IDH 2007, 2008, 2009, 2010

\begin{tabular}{lllll}
\hline Countries & $\mathbf{2 0 0 7}$ & $\mathbf{2 0 0 8}$ & $\mathbf{2 0 0 9}$ & $\mathbf{2 0 1 0}$ \\
\hline Argentina & 0.764 & 0.769 & 0.772 & 0.775 \\
Australia & 0.931 & 0.933 & 0.935 & 0.937 \\
Austria & 0.846 & 0.849 & 0.849 & 0.851 \\
Bangladesh & 0.449 & 0.457 & 0.463 & 0.469 \\
Belgium & 0.864 & 0.865 & 0.865 & 0.867 \\
Bolivia & 0.625 & 0.632 & 0.637 & 0.643 \\
Brazil & 0.685 & 0.690 & 0.693 & 0.699 \\
Brunei Darussalam & 0.804 & 0.804 & 0.804 & 0.805 \\
Bulgaria & 0.736 & 0.741 & 0.741 & 0.743 \\
Canada & 0.885 & 0.886 & 0.886 & 0.888 \\
Chile & 0.773 & 0.778 & 0.779 & 0.783 \\
China & 0.639 & 0.648 & 0.655 & 0.663 \\
Colombia & 0.676 & 0.681 & 0.685 & 0.689 \\
Costa Rica & 0.719 & 0.722 & 0.723 & 0.725 \\
Cyprus & 0.804 & 0.807 & 0.809 & 0.810 \\
Czech Republic & 0.843 & 0.844 & 0.841 & 0.841 \\
Denmark & 0.864 & 0.865 & 0.864 & 0.866 \\
Egypt & 0.601 & 0.608 & 0.614 & 0.620 \\
Estonia & 0.816 & 0.816 & 0.809 & 0.812 \\
Finland & 0.870 & 0.871 & 0.869 & 0.871 \\
France & 0.864 & 0.867 & 0.869 & 0.872 \\
Germany & 0.883 & 0.885 & 0.883 & 0.885 \\
Greece & 0.847 & 0.851 & 0.853 & 0.855 \\
Guatemala & 0.550 & 0.554 & 0.556 & 0.560 \\
Hong Kong, China & 0.855 & 0.856 & 0.857 & 0.862 \\
Hungary & 0.803 & 0.804 & 0.803 & 0.805 \\
Iceland & 0.888 & 0.870 & 0.869 & 0.869 \\
\hline
\end{tabular}


Appendix 2. Contd.

\begin{tabular}{lllll}
\hline India & 0.500 & 0.506 & 0.512 & 0.519 \\
Indonesia & 0.580 & 0.588 & 0.593 & 0.600 \\
Iran (Islamic Republic of) & 0.684 & 0.691 & 0.697 & 0.702 \\
Ireland & 0.896 & 0.896 & 0.894 & 0.895 \\
Israel & 0.869 & 0.870 & 0.871 & 0.872 \\
Italy & 0.848 & 0.850 & 0.851 & 0.854 \\
Japan & 0.880 & 0.881 & 0.881 & 0.884 \\
Korea (Republic of) & 0.865 & 0.870 & 0.872 & 0.877 \\
Latvia & 0.777 & 0.777 & 0.769 & 0.769 \\
Lithuania & 0.785 & 0.789 & 0.782 & 0.783 \\
Luxembourg & 0.861 & 0.851 & 0.850 & 0.852 \\
Malaysia & 0.735 & 0.738 & 0.739 & 0.744 \\
Malta & 0.809 & 0.812 & 0.813 & 0.815 \\
Mexico & 0.742 & 0.745 & 0.745 & 0.750 \\
Netherlands & 0.886 & 0.888 & 0.888 & 0.890 \\
New Zealand & 0.903 & 0.903 & 0.904 & 0.907 \\
Nigeria & 0.412 & 0.416 & 0.419 & 0.423 \\
Norway & 0.937 & 0.937 & 0.937 & 0.938 \\
Pakistan & 0.481 & 0.484 & 0.487 & 0.490 \\
Papua New Guinea & 0.415 & 0.421 & 0.426 & 0.431 \\
Paraguay & 0.631 & 0.635 & 0.634 & 0.640 \\
Peru & 0.707 & 0.715 & 0.718 & 0.723 \\
Philippines & 0.628 & 0.633 & 0.635 & 0.638 \\
Poland & 0.784 & 0.788 & 0.791 & 0.795 \\
Portugal & 0.785 & 0.789 & 0.791 & 0.795 \\
Romania & 0.754 & 0.765 & 0.764 & 0.767 \\
Russian Federation & 0.708 & 0.715 & 0.714 & 0.719 \\
Saudi Arabia & 0.741 & 0.746 & 0.748 & 0.752 \\
Singapore & 0.836 & 0.839 & 0.841 & 0.846 \\
Slovakia & 0.811 & 0.816 & 0.815 & 0.818 \\
Slovenia & 0.825 & 0.828 & 0.826 & 0.828 \\
South Africa & 0.590 & 0.592 & 0.594 & 0.597 \\
Spain & 0.857 & 0.861 & 0.861 & 0.863 \\
Sweden & 0.885 & 0.885 & 0.884 & 0.885 \\
Switzerland & 0.876 & 0.871 & 0.872 & 0.874 \\
Thailand & 0.642 & 0.646 & 0.648 & 0.654 \\
Turkey & 0.672 & 0.674 & 0.674 & 0.679 \\
United Kingdom & 0.845 & 0.847 & 0.847 & 0.849 \\
United States & 0.899 & 0.900 & 0.899 & 0.902 \\
Uruguay & 0.749 & 0.756 & 0.760 & 0.765 \\
Viet Nam & 0.560 & 0.566 & 0.572 \\
\hline Soure: own & & & & \\
\hline
\end{tabular}

Source: own work from UNDP (2010). 